\title{
Repatriation and the Threat to Objective Knowledge
}

\author{
Elizabeth Weiss
}

James W. Springer

The subject of this article is the repatriation movement in the United States, which we define as any effort to restrict research into aboriginal North American culture and biology, including demands that human remains and artifacts be turned over to Indian tribes. We include any movement that seeks to limit research on Native Americans to matters and opinions that are approved by the tribes or their presumed spokesmen. We disagree with the repatriation movement on the basis that it promotes racial and religious discrimination.

Although there are several federal laws that give Indian tribes and people legal rights and powers not granted to others, the federal statute with the most implications for the study of human remains is the Native American Graves Protection and Repatriation Act (NAGPRA). In accordance with NAGPRA Native American human remains and cultural items discovered or excavated on federal lands or tribal lands after November 16, 1990, shall be given to lineal descendants of the Native Americans whose remains are found, the tribe on whose land such objects were found, or the tribe that has the closest cultural affiliation with the remains, or, for culturally unaffiliated objects, the tribe recognized by a final judgment of the Indian Claims Commission as having aboriginally occupied the area. For objects and remains recovered before that date, any institution receiving federal support is required to produce an inventory of human remains and associated funerary objects, to give notice to Indian tribes, to consult with Indian tribes, and to repatriate remains to those tribes which claim them.

Where an inventory of the remains has not been prepared or remains were not included in those documents, then upon request such remains "shall be expeditiously returned where the requesting Indian tribe or Native Hawaiian

James W. Springer is a retired attorney; jamesspringer833@gmail.com. Elizabeth Weiss is a professor of anthropology at San José State University; Elizabeth.Weiss@sjsu.edu. Weiss and Springer are co-authors of Repatriation and Erasing the Past (University of Florida Press, 2020). 
organization can show cultural affiliation by a preponderance of the evidence based upon geographical, kinship, biological, archaeological, anthropological, linguistic, folkloric, oral tradition, historical, or other relevant information or expert opinion.” Any agency failing to comply with these requirements will be assessed a civil penalty.

NAGPRA directs the Secretary of the Interior to establish a committee to "monitor and review" the progress of repatriation. There shall be seven members on the committee, "three of whom shall be appointed by the Secretary from nominations submitted by Indian tribes, Native Hawaiian organizations, and traditional Native American religious leaders, with at least two of such persons being traditional Indian religious leaders."

NAGPRA strongly favors repatriation, which is well-illustrated in the Kennewick Man case. ${ }^{1}$ In 1996, two teenagers found a skull along the water's edge of the Columbia River in Kennewick, Washington. Anthropologist James Chatters salvaged the 8,500 year old skeleton. The find and the ensuing controversy epitomize the hostility of Indian activists to scientific studies and the extraordinary bias of the federal agencies in deferring to Indian activists.

Chatters did a preliminary study of the bones after which he arranged with physical anthropologist Douglas Owsley to have the skeleton removed to the Smithsonian Institution for further study. Before that occurred, the U.S. Army Corps of Engineers seized the skeleton, announced its intention of turning it over to the Indian claimants under NAGPRA, and refused to allow any further study. After a team of anthropologists filed suit to allow study of the find and prevent its repatriation, the Department of the Interior took custody of the skeleton and the defense of the suit and the case proceeded.

Based on Chatters' preliminary data, the anthropologists presented evidence to the district court that Kennewick Man's skeletal morphology was distinguishable from that of modern Native Americans and that it could not be reasonably linked to a member of any known tribe. The defendant governmental agencies offered broad generalizations through expert opinion about prehistoric archaeology, linguistics, and folklore/religion of the Pacific Northwest, while the Indian intervenors offered their oral traditions, which incorporated supernatural events. The district court ruled, and the circuit affirmed, that the government and the Indian defendants had not proven a relationship between

1 Douglas W. Owsley, Richard J. Jantz, eds., Kennewick Man: The scientific investigation of an ancient American skeleton (College Station: Texas A \& M University Press, 2014). 
Kennewick Man and any historic Indian tribe, and that the government's denial of the plaintiffs' right to study the remains was illegal. As a result, study was allowed and the result was a magnificent volume of scientific research.

Yet two issues are particularly disturbing. The Indian claimants attempted to prevent any scientific research on the grounds that they already knew the identity of the "Ancient One," as they called the skeleton. They knew their past through oral tradition and did not want any contradiction of that tradition by scientific research.

The second disturbing issue was the enormous favoritism shown by the government agencies to the Indian claimants, and their prejudice against scientific research. These included secret communications of information and legal strategies to the Indian claimants, granting them access to the remains despite court orders, and burying the discovery site under tons of fill to prevent any further investigation.

In 2015, a team led by anthropologist Morten Rasmussen published Kennewick Man's sequenced DNA in Nature and concluded that Kennewick Man was “Native American," based upon genetic similarities to the modern population of the Colville Reservation, one of the Indian claimants. The fallacies of the Native American conclusion are many. The figures in the article actually show that Kennewick Man's closest ties are with contemporary Indian populations of Central and South America. The lack of good DNA coverage for contemporary North American Indians, due to opposition by activists, means that it is impossible to do a comparison that will show which contemporary group is most like Kennewick Man. There are, in fact, no physical anthropological criteria, whether morphological, genetic, or other, that are unique to any particular tribe. Disturbingly, when geneticist David Reich asked for the data from Rasmussen and colleagues' paper, he was refused, although provision of such data is a prerequisite for studies published in Nature. ${ }^{2}$ Most disturbingly, based upon such faulty conclusions, Kennewick Man was reburied.

We disagree with the repatriation movement generally and NAGPRA specifically because of the racial and religious discrimination that the movement and law support, and the establishment of religion inherent in NAGPRA.

Until the 1950's (before school desegregation decisions declared legally enforced racial discrimination unconstitutional) legislatures and courts

2 David Reich, Who We Are and How We Got Here (New York: Pantheon Books, 2018), 166-68. 
generally assumed that certain forms of racial discrimination were constitutionally permissible and perhaps in some contexts desirable. ${ }^{3}$ American Indians generally, and each Indian tribe, were traditionally considered as separate "races," whose defining characteristics might be ancestry, genetic traits, physical types, or language. Courts were frank in admitting that Indian law was based on imposing burdens and granting rights and powers based on race, as illustrated in United States v. Rogers, 45 U.S. 507 (1845). Such frank discrimination has become something of an embarrassment, and more recently some litigants and judges have claimed that the special treatment of Indians is "political" rather than "racial." ${ }^{4}$ but the distinction is mere semantics. In any other context, special treatment for any ethnic group would be recognized as racial discrimination and reviewed under a strict scrutiny standard. ${ }^{5}$

Almost all British North American colonies explicitly established monotheistic religion. Establishments varied from tax subsidies for particular churches to religious tests for public office to criminal proceedings against religious nonconformists. At the beginning of the American Revolution, the former colonies, now independent states, proceeded to weaken their church establishments and move toward greater religious freedom.

The original U.S. Constitution, ratified in 1788, forbade religious tests for federal office (Article VI). James Madison introduced into the First Congress a series of proposed amendments, ten of which were passed by Congress and ratified by the states and became the Bill of Rights. ${ }^{6}$

The policy of the British North Americans was disestablishmentarianism combined with monotheistic endorsement. The two clauses reflected two cooperating impulses: the disgust with religious discrimination, persecution, and warfare of recent European and American history, and the view that each person ought to be free to worship God in whatever manner he chose ("the sacred rights of conscience"), combined with the view that religion was a valuable, perhaps necessary, support to the morality and virtue that were essential for a republican government. ${ }^{7}$

3 See Richard Rothstein, The Color of Law: A forgotten history of how our government segregated America (New York: Liveright, 2017).

4 See Morton v. Mancari, 417 U.S. 535, 554 n. 24 (1974).

5 See Adarand Constructors, Inc. v. Pena, 515 U.S. 200 (1995).

6 Neil H. Cogan, ed. The Complete Bill of Rights (New York: Oxford University Press, 1997).

7 Daniel L. Dreisbach, and Mark D. Hall, The sacred rights of conscience: selected readings on religious liberty and church-state relations in the American founding (Indianapolis: Liberty Fund, 2009). 
That the benefits and protections of the First Amendment extend to American Indian individuals, religions, and tribes has been affirmed by the courts, but presents many problems because American Indian religions lack such recognizable features as permanent buildings used as places of worship, official religious writings, a professional priesthood, and official religious doctrines characteristic of monotheistic religions.

Starting with the Free Exercise Clause, secular laws of general application, such as public safety laws, can legitimately be applied to religious believers and institutions, as long as any burden they impose on religious practice and belief is merely incidental. Except for the conscientious objector cases, to successfully assert a free exercise defense to a general law, a claimant must show that his beliefs and practices are part of the established and accepted doctrines of a recognizable church, and not purely idiosyncratic.

For example, in Badoni v. Higginson, 455 F. Supp. 641 (D. Utah, C.D. 1977), aff'd. 638 F. 2 d 172 (10 ${ }^{\text {th }}$ Cir. 1980), cert. denied sub nom. Badoni v. Broadbent, 452 U.S. 954 (1981), individual Navajos and chapters of the Navajo Nation sued to enjoin the flooding of a portion of the Rainbow Bridge National Monument, on the First Amendment grounds that it was sacred to them. Drowning of holy sites and prevention of access to them would produce emotional injury to the plaintiffs and frustrate their prayers to their gods. The district court granted summary judgment to the defendant in part on the grounds that the plaintiffs had not proven that their ceremonies were part of a religion recognized by the Navajo Nation, which is difficult to do because American Indian religions lack official written doctrines. The Tenth Circuit affirmed summary judgment on the grounds that what the plaintiffs were seeking was affirmative government action in support of their religion, which would violate the Establishment Clause.

Although it has been frequently criticized, the test stated in Lemon v. Kurtzman, 403 U.S. 607 612-613 (1971) has exerted great influence in Establishment Clause decisions: "First, the statute must have a secular legislative purpose; second, its principal or primary effect must be one that neither advances nor inhibits religion; finally, the statute must not foster 'an excessive entanglement with religion."” Thus, a government agency may not favor religious beliefs over secular knowledge or scientific theories. And, government sponsored prayers and displays of, or endorsements of, particular religious texts or symbols are usually found to be unconstitutional. 
NAGPRA's constitutionality under these principles is precarious. The statute specifies that the official NAGPRA committee shall include three individuals nominated by Indian tribes and Native Hawaiian Organizations and at least two of such persons must be “traditional Indian religious leaders.” To specify that a government committee must include religious leaders of a particular race and religion is contrary to all of the statutes and court decisions that forbid even milder forms of discrimination. This obvious violation of the Lemon test was briefly recognized by one of the Kennewick Man decisions, Bonnichsen v. U.S. Dept. of Army, 969 F. Supp. 628, 643-644 (D. Oregon 1997), but only in a superficial and dismissive way. No other court, to our knowledge, has even considered this obvious constitutional problem.

One of the ways that NAGPRA has established a religion is little known outside of those who work directly on consultation committees between anthropologists and tribal representatives. Such meetings generally begin and end with Native American prayers in a language that the anthropological representatives cannot understand. Such forced participation in prayer as part of an official governmental function would be found to violate the First Amendment in any other context, and there is no good reason to treat NAGPRA consultation committees as an exception. Religious taboos are used to limit what areas of a site can be excavated and who can conduct the research, such as restrictions on female researchers. ${ }^{8}$

The NAGPRA Committee's membership restriction to "traditional Indian religious leaders," quite apart from its discriminatory content, is in obvious violation of the ordinary rules of the First Amendment against the government's having to ascertain the orthodox principles of any religion. Many contemporary Indians practice a complex mixture of practices: some seem pre-Columbian while others are obviously of more recent origin. Anthropologist Charles Lange noted in his 1968 book that the Eastern Pueblo of New Mexico combine Catholic Christianity with the pre-Columbian kachina cult. In his 1972 work on the Handsome Lake religion of the Iroquois, Anthony Wallace noted that very likely pre-Columbian rituals were combined with references to Jesus Christ. What qualifies as "traditional Indian religion” is problematic and determining such would require an official inquiry into the orthodoxy of the beliefs at issue. Such an inquiry was, in fact, conducted in the Badoni case, as noted above.

8 Elizabeth Weiss, "Repatriation, Religion, and Rights" last modified September 9, 2020, https://libertyunbound.com/repatriation-religion-and-rights. 
One of the most disturbing court practices has been to accept Indian oral traditions of supernatural events as evidence. For example, Zuni religion became a source of evidence accepted by the court in Zuni Tribe of New Mexico $v$. United States, 12 Cl.Ct. 607 (1987). The Zuni claimed ownership rights to a huge area of Arizona and New Mexico, much larger than their reservation. To support their claims, the Zuni offered evidence in the form of historical documents and archaeology, but they also offered religious evidence. These stories told of the Zunis' origin as underground water dwellers (with webbed hands and feet, tails and horns, no mouths or anuses) who emerged at the bottom of the Grand Canyon supervised and instructed by gods. Their migration stories contain accounts of gods, monsters, magical transformations, and ritual contests to create soil and water. The Zuni witnesses identified various locations in Arizona and New Mexico where these events occurred and claimed ownership based upon these stories.

The government's attorneys objected to the court's acceptance of these stories as evidence, but the judge overruled their objections while acknowledging that the stories were "religious history" and that "oral recounting through generations can become less than accurate." But the court was persuaded by "the testimony of plaintiff's experts that, to the Zunis as to members of other tribes, the transmission of historical data and tradition was always of great import with little, if any, reliance placed on written documentation.” Finally, the court noted that the defendant conjectures "offers little evidence to contradict or impeach the Zuni recounting of their history."

Yet, the much larger problem, which the court ignores, is that the evidentiary value of the origin and migration stories is inextricably bound up with their religious content. To prove where an event occurred one must at least assume that it is possible for that sort of event to occur. The issue is not simply whether the Zuni lived underground and received instruction from their gods, but whether a court may properly receive this sort of testimony, considering the strictures of the First Amendment. The court simply assumes that it is up to the government lawyers to provide contrary evidence or to impeach the Zuni witnesses. A more fundamental question is whether stories of the divine, the magical, and the supernatural should be accepted as evidence.

In conclusion, repatriation is the assertion of the superior legal and moral rights of a particular racial group (American Indians) against all other racial groups. Repatriationists claim the right to determine what shall be the 
orthodoxy for all studies of American Indian biology and culture, to censor and suppress competing views, and to have their religious views enforced as a matter of legal right and governmental policy. As one of them put it, "We want to be the ones who tell our story."

Ancient DNA research throughout North America is facing increasing censorship problems, as highlighted by archaeologist Bruce Bourque, who gave examples ranging from the cancellation of DNA research on 4,000 year old Newfoundland remains, to the lack of publication of DNA data from the 4,000 year old Nevin site in Maine, to Brown University's 2019 ancient DNA conference at which researchers were essentially told to use myths rather than scientific evidence to reconstruct the past. ${ }^{10}$ Some of the more extreme assertions of censorship and control by Native Americans occur on the website of the American Indian \& Alaska Native Genetics Resource Center (http://genetics.ncai.org). The Resource Center is particularly concerned that research into Native American genetics might be used to support the theory that the first humans in the New World migrated there from Siberia. Such a theory, or indeed, any theory based upon empirical evidence, would contradict traditional Native American stories of a supernatural origin. Hostility to the hypothesis of a Siberian origin, not mere disagreement with it, is a recurring theme in the repatriation literature, such as Vine Deloria's 1997 Red Earth, White Lies: Native Americans and the myth of scientific fact or Kathleen Fine-Dare's 2002 Grave Injustice: the American Indian repatriation movement and NAGPRA, where the hypothesis is condemned as a lie propounded by white racists trying to pass themselves off as objective scientists. Neither of the authors just cited, nor the Resource Center, bother to attempt to refute, or even acknowledge the large body of scientific knowledge of Beringia (from geology, paleontology, palynology, and archaeology) and its bearing on human migrations.

We reject the view that the members of any ethnic, racial, or tribal group have the sole right to tell "our story," because that story is not solely theirs. Anthropology is a discipline that considers all biological and cultural divisions of the human species to be its proper subject. Even those fields that make less claim to universality are open to anyone who is willing to accept the discipline

9 Ewen Callaway, "North America's oldest mummy returned to US tribe after genome sequencing," Nature News 540, no. 7632 (2016): 178

10 Bruce Bourque, "The Campaign to Thwart Paleogenetic Research Into North America's Indigenous Peoples," Quillette, March 29, 2021, https://quillette.com/2021/03/29/the-campaign-to-thwart-paleogenetic-research-into-north-americas-indigenous-peoples/. 
of scholarship along with the right to participate of all other individuals willing to accept that discipline. Springer spent a period of time studying the role of American Indians in colonial British law in North America and found that the most accomplished scholar of that subject was Yasuhide Kawashima, a man born and educated in Japan who made himself a world authority on the law of British North America as applied to Native Americans. It would be narrow minded (to use no stronger term) for any person to disparage Kawashima's work because he was telling something that was not "his" story.

To oppose the ideology of racial control of knowledge, we offer the philosophy of objective knowledge as articulated by Karl Popper, ${ }^{11}$ Karl Popper and John Eccles, ${ }^{12}$ and William Bartley III. ${ }^{13}$ These authors define three worlds of which we can have knowledge. World One is the world of material objects, including inanimate objects, organisms, and artifacts insofar as their physical properties are concerned. World Two is the world of mental activity: perception, consciousness, and self-consciousness. World Three consists of "objective contents of thought," ${ }^{14}$ which include books and other records, artifacts, and works of art. The most important elements of World Three are the problems, arguments, and discussions expressed in some extrasomatic form, such as books.

One of the defining characteristics of World Three is the lack of control over it by any individual, authority, group, or institution. Certain individuals exert more influence than others, and their opinions are more widely circulated and respected. However, there are always dissenters, naysayers, and deniers from even the most prestigious leaders and doctrines. Indeed, what is respected, deferred to, or accepted as most nearly definitive will commonly change from one generation to the next. No individual has any status as an authority or expert except to the extent that his arguments justify that status.

Any individual, no matter how vast his knowledge, will be familiar with only a tiny part of World Three and will be an expert in an even tinier part. More importantly, he will not be able to anticipate, much less control, how his contribution to World Three will be received and used. His statements will be

11 Karl R. Popper, Objective knowledge: An evolutionary approach, revised edition, (Oxford: Oxford University Press, 1979), 106-190.

12 Karl R. Popper, John C. Eccles, The self and its brain (London: Routledge \& Kegan Paul, 1983).

13 William Bartley III, "Alienation alienated: The economics of knowledge versus the psychology and sociology of knowledge," in Evolutionary Epistemology, Rationality, and the Sociology of Knowledge, eds. Gerard Radnitzky, and William W. Bartley III (LaSalle: Open Court, 1987), 423-51.

14 Popper, 1979, 106. 
restated, paraphrased, and perhaps misstated and misinterpreted, at least from his point of view. They will be used in ways that he could not have anticipated and perhaps for purposes that he would not have approved. As Bartley puts it, "Knowledge is a product not fully known to its producers," ${ }^{15}$ or, as Popper puts it, World 3 is "epistemology without a knowing subject." ${ }^{16}$ World Three and its objective knowledge offer us a way out of the ethnic and racial collectivism of the repatriation movement. 